\title{
Estimulação transcraniana por corrente contínua em crianças e adolescentes com autismo: desfechos motores
}

\author{
Transcranial direct current stimulation in children and \\ adolescents with austim spectrum disorder: motor outcomes
}

\author{
Mariana Lessa de Castro' ${ }^{1}$ \\ Patrícia Vieira de Oliveira ${ }^{2}$ (1) \\ Luanda A. Collange 3 (1) \\ Mauro Muszkat ${ }^{4}$ (1) \\ Sueli Rizzutti 5 (1)
}

`Autora para correspondência. Laboratório de Neuromodulação e Desenvolvimento, Universidade Federal de São Paulo (São Paulo). São Paulo, Brasil. marilessa@hotmail.com,

2,4,5Autora para correspondência. Laboratório de Neuromodulação e Desenvolvimento, Universidade Federal de São Paulo (São Paulo). São Paulo, Brasil. patricia@prvo.com.br, mauromuszkat@uol.com.br, surizzutti@gmail.com

3universidade de Sorocaba (Sorocaba). São Paulo, Brasil, luandacollange@hotmail.com

RESUMO | INTRODUÇÃO: O Transtorno do Espectro Autista (TEA) é uma complexa alteração do neurodesenvolvimento de início precoce, com sintomas presentes nos três primeiros anos de vida, segundo os critérios de classificação do Diagnostic and Statistical Manual of Mental Disorders 5 (DSM-5) $)^{1}$. Caracterizado por alterações na comunicação social e em domínios comportamentais, incluindo comportamentos repetitivos e estereotipados, estima-se uma taxa de prevalência de um em cada 110 nascimentos ${ }^{2}$. O TEA é bastante complexo do ponto de vista sintomatológico, podendo levar a cursos clínicos bastante heterogêneos. A complexidade do TEA torna necessária a abordagem multiprofissional de intervenção terapêutica, permitindo a estimulação de diferentes habilidades comportamentais, de interação social, cognitivas, bem como nas dificuldades motoras ${ }^{3}$. Um crescente interesse nos efeitos da neuromodulação não invasiva, particularmente a estimulação transcraniana por corrente contínua (ETCC), vem sendo observado na literatura científica, com resultados promissores observados no TEA ${ }^{4,5}$. Considerando as possibilidades terapêuticas, a pergunta norteadora deste estudo foi se a aplicação da ETCC anódica na área do córtex pré-frontal dorsolateral (CPFDL) do hemisfério cerebral esquerdo associada à estimulação de habilidades cognitivas e sensoriais poderia melhorar as respostas motoras no TEA. Ainda há uma lacuna na literatura sobre intervenções para o desenvolvimento motor, bem como poucos estudos do tipo ensaio clínico com ETCC em população pediátrica e adolescente no TEA. Assim, o desenho do estudo, a qualidade metodológica e o acompanhamento dos efeitos com follow-up de três meses justificam este estudo. OBJETIVOS: Comparar os efeitos da ETCC anódica sobre o CPFDL esquerdo com efeitos da estimulação sham sobre a motricidade de crianças e adolescentes com TEA. MATERIAIS E MÉTODOS: O estudo foi realizado no período de novembro de 2018 a janeiro de 2020, no Núcleo de Atendimento Neuropsicológico Infantil Interdisciplinar (NANI), obedecendo às Diretrizes e Normas Regulamentadoras de pesquisa envolvendo seres humanos, formuladas pelo Conselho Nacional de Saúde, Ministério da Saúde, conforme a Resolução 466/2012, no Brasil. Foi aprovado pelo Comitê de Ética da Universidade Federal 
de São Paulo sob parecer de número 3.439 .584 e registro número RBR-9737g8. Os responsáveis por todos os participantes assinaram um Termo de Consentimento Livre e Esclarecido, declarando ter ciência de que o procedimento ao qual se submeteram foi voluntário, gratuito e experimental. Foi realizado um ensaio clínico cruzado, controlado, randomizado e duplo cego no qual participaram 18 crianças e adolescentes que atenderam aos seguintes critérios de inclusão: a) diagnóstico de TEA, segundo o DSM-5; b) idade entre 6 e 12 anos; c) que realizassem tratamento comportamental e/ou medicamentoso para TEA; d) inseridas no ambiente escolar; e) possuíssem graus de compreensão e colaboração compatíveis com a realização das atividades propostas (avaliado durante a execução das tarefas da Escala de Desenvolvimento Motor pré-intervenção. As crianças que realizaram todas as tarefas foram incluídas para as demais etapas). Foram excluídas crianças portadoras de outros transtornos neurológicos ou psiquiátricos, com epilepsia, que possuíssem implante metálico no encéfalo ou aparelhos auditivos, e crianças com deficiências intelectuais, sensoriais ou motoras que limitassem a realização das atividades propostas neste projeto. A intervenção foi constituída por dez sessões de ETCC anódica de $1 \mathrm{~mA}$ sobre o CPFDL esquerdo, por 20 minutos, associadas a tarefas e jogos de atenção, memória e estímulos sensoriais. A estimulação foi aplicada com um aparelho de ETCC ( $D C$ Stimulator mobile- Neuroconn), por meio de dois eletrodos-esponja de $5 \times 7 \mathrm{~cm} 2$ de superfície, umedecidos em solução salina. Foi utilizada uma rampa de subida e descida de 30 segundos. 0 tipo de estimulação (ativa ou sham) foi feita respeitando a distribuição aleatória dos participantes em um dos dois grupos estudados. A randomização foi feita através de envelopes numerados, opacos e selados para garantir a confidencialidade. Cada envelope continha um cartão estipulando a qual intervenção inicial o participante seria alocado. Este processo foi feito por um membro da equipe que não estava envolvido no processo de recrutamento ou desenvolvimento da pesquisa. Desta forma nem os participantes (e seus responsáveis) souberam a que grupo foram designados, assim como os avaliadores que aplicaram a escala. Tanto no grupo experimental como no controle, o elétrodo ânodo foi posicionado sobre o CPFDL esquerdo e o cátodo sobre a região do músculo deltóide contralateral. No grupo controle, o estimulador foi ligado durante 30 segundos, sendo desligado em seguida, assim os participantes puderam vivenciar a sensação inicial da corrente, mas sem receber a estimulação no tempo restante. Após 3 meses de wash-out, os grupos foram cruzados e passaram por nova etapa de intervenção de 10 dias (ativa ou sham). Os desfechos motores foram avaliados pela Escala de Desenvolvimento Motor de Francisco Rosa Neto (EDM) nos momentos pré, pós (10 dias) e 3 meses após as intervenções. A EDM é composta por testes que avaliam o desenvolvimento motor de crianças entre seis e onze anos de idade, e abrange 6 dimensões da motricidade humana, bem como a lateralidade. As provas de avaliação são realizadas de acordo com a faixa etária da criança, em níveis progressivos de dificuldade. A idade motora (IM) é calculada através do resultado dos testes de cada uma das áreas expressa em meses. A idade motora geral (IMG) é calculada através da somatória dos resultados de cada uma das áreas expressa em meses, dividida por 6 (número de áreas avaliadas, sendo: motricidade fina, motricidade global, equilíbrio, esquema corporal, organização espacial e organização temporal e linguagem). RESULTADOS: Uma amostra de 18 crianças e adolescentes completou todas as etapas de intervenção e avaliações, sendo 14 do sexo masculino e 4 do sexo feminino, com idade média de 8,7 anos ( $D P=1,95)$. Na avaliação inicial, todos os participantes apresentaram IMG inferior ao esperado para sua idade cronológica. Quanto à intervenção com a ETCC, não foram observados efeitos adversos moderados ou graves ao longo do estudo. O teste de Kolmogorov-Smirnov demonstrou distribuição normal dos dados. Assim, foram realizados testes paramétricos e os dados foram expressos em média e desvio padrão. A análise de variância (ANOVA) de medidas repetidas, com o teste post hoc de Bonferroni foram utilizadas para determinar o efeito da ETCC anódica sobre o CPFDL (ativa e sham) sobre as variáveis motoras estudadas. Um valor de $p<0,05$ foi considerado indicativo de significância estatística. Quanto à comparação dos efeitos da ETCC, a ANOVA de medidas repetidas mostrou haver diferença significante na IMG $(F(1,9)=3,7 ; p=0,01)$. Especificamente, a análise post hoc demonstrou que em comparação com a intervenção envolvendo a estimulação transcraniana sham, a intervenção com ETCC ativa resultou em médias superiores na avaliação de acompanhamento três meses após o término da intervenção na IMG ( $p<0,05$ para todas as comparações), conforme apresentado no Gráfico 1. 


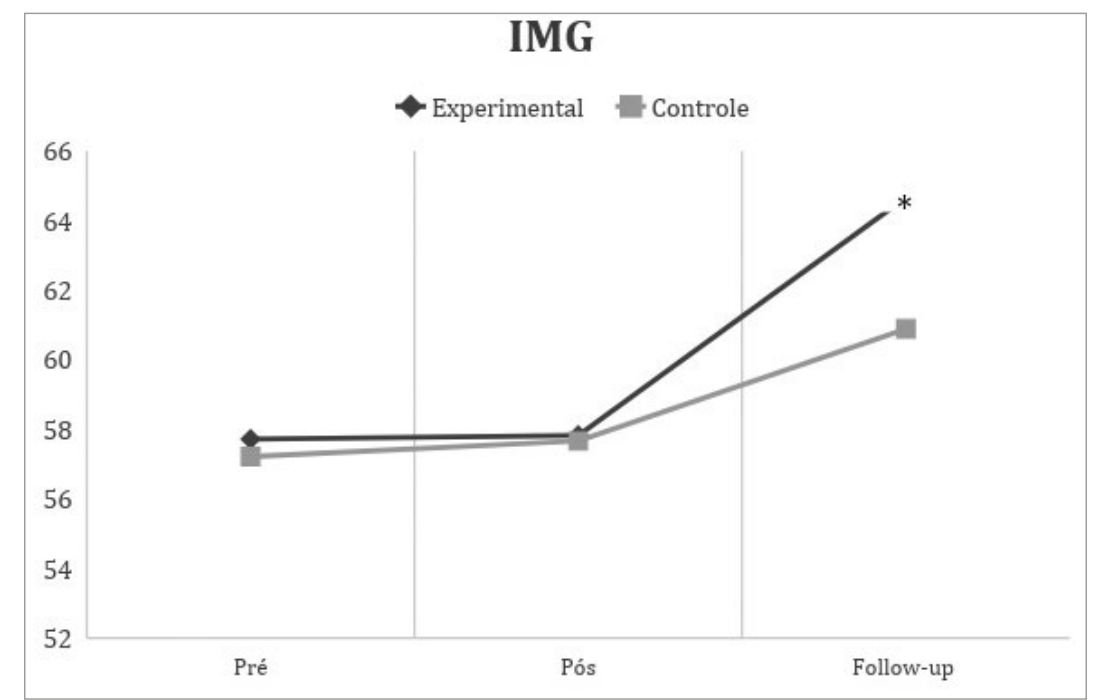

O quadro 1 apresenta os resultados em médias e desvio padrão para cada intervenção:

Quadro 1. IMG expressa em médias e desvio-padrão; * $\mathrm{P}<0,05$

\begin{tabular}{|cccc|ccc|}
\hline \multicolumn{4}{|c|}{ Experimental } & \multicolumn{2}{c|}{ Controle } \\
\hline & Pré & Pós & Follow-up & Pré & Pós \\
\hline IMG & $57,72 \pm 19,30$ & $57,83 \pm 17,32$ & $64,67 \pm 20,24^{*}$ & $57,22 \pm 18,99$ & $57,67 \pm 18,91$ & $60,89 \pm 19,34$ \\
\hline
\end{tabular}

Os resultados deste estudo demonstram que não houve diferença estatística significativa entre as intervenções ativa e sham da ETCC nos momentos pré e pós-intervenção. As maiores médias foram encontradas após as intervenções com ETCC anódica ativa nas avaliações de follow-up de 3 meses. O aumento da IMG demonstra que houve uma melhora do perfil motor da criança, isto é, uma redução da idade negativa, apontando que o desempenho motor geral se aproximou mais do desempenho esperado para sua idade cronológica. Uma hipótese para este resultado se correlaciona com os achados nos estudos incluídos na revisão sistemática de Moura et al. $\cdot$, em que a maior ativação do CPFDL, promovendo a reorganização dos recursos atencionais e das áreas executivas que elaboram as ações motoras pode ter favorecido o desempenho motor, pois as tarefas motoras eram orientadas e demandavam atenção tanto aos comandos dados pela avaliadora como a atenção inerente à própria tarefa. Os achados deste estudo corroboram com estudos preliminares, que demonstram que os efeitos da ETCC podem perdurar por 3 meses após sua aplicação ${ }^{5,7}$. CONCLUSÃO: A aplicação da ETCC anódica no CPFDL esquerdo demonstrou efeitos positivos nas respostas motoras de crianças e adolescentes com TEA após três meses de sua aplicação.

PALAVRAS-CHAVE: Autismo. Estimulação transcraniana por corrente contínua. Desenvolvimento Motor. 
ABSTRACT | INTRODUCTION: Autistic Spectrum Disorder (ASD) is a complex neurodevelopment disorder with early symptoms present in the first three years of life according to the Diagnostic and Statistical Manual of Mental Disorders 5 (DSM$5)^{1}$. It is characterized by changes in the social and behavioral domains, including repetitive and stereotyped behaviors. The prevalence rate is estimated in one in 110 births $^{2}$. In addition, from the symptomatic and behavioral point of view, ASD is quite complex which can lead to very heterogeneous clinical courses. The complexity of ASD leads to a multiprofessional therapeutic intervention approach to allow the stimulation of different skills involved in both behavioral, social interaction, cognitive issues, as well as motor impairments ${ }^{3}$. A growing interest in the effects of non-invasive neuromodulation, particularly transcranial direct current stimulation (tDCS), has been observed in the scientific literature, with promising results observed in controlled and randomized clinical trials in ASD 4,5 . Considering the therapeutic possibilities, the guiding question of this study was whether the application of anodic tDCS in the dorsolateral prefrontal cortex (DLPFC) of the left cerebral hemisphere associated with cognitive and sensory abilities stimuli could improve motor responses in ASD. There is still a gap in the literature on interventions for motor development, as well as few clinical trials studies with tDCS in pediatric and adolescent populations in ASD. Thus, the study design, methodological quality and monitoring of effects with a three-month follow-up justify this study. OBJECTIVES: The objective of the study was to compare the effects of anodic tDCS on left DLPFC with effects of sham stimulation on the motor skills of children and adolescents with ASD. MATERIALS

AND METHODS: The study was carried out from November 2018 to January 2020, at the Center for Interdisciplinary Child Neuropsychological Care (NANI). It complies with the Regulatory Guidelines and Norms for research involving human beings, formulated by the National Health Council, Ministry of Health, according to Resolution 466/2012, in Brazil. It was approved by the Ethics Committee of the Federal University of São Paulo under number 3.439.584 and register number RBR-9737g8. Those responsible for all the participants signed a Free and Informed Consent Form, declaring that they were aware that the procedure they underwent was voluntary, free and experimental. Eighteen children and adolescents who met the inclusion criteria participated in this controlled, randomized, double-blind and crossover clinical trial. The inclusion criteria were: a) children and adolescents diagnosed with ASD, according to DSM-5; b) age between 6 and 12 years; c) performed behavioral and / or drug treatment for ASD; d) inserted in the school environment; e) understanding and collaboration compatible with the performance of the proposed activities (which was assessed during the execution of the pre-intervention Motor Development Scale tasks. Those who performed all tasks were included). Children with other neurological or psychiatric disorders, with epilepsy, who had a metallic implant in the brain or hearing device, and children with intellectual, sensory or motor disabilities that limited the performance of the activities proposed in this project were excluded. The study intervention consisted of ten sessions of anodic $1 \mathrm{~mA}$ tDCS over the DLPFC, for 20 minutes, associated with tasks and games of attention, memory and sensory stimuli. The stimulation was applied with a tDCS device (DC-Stimulator mobileNeuroconn), using two $5 \times 7 \mathrm{~cm} 2$ sponge electrodes surface, moistened in saline solution. A 60-second up and down ramp was used. The type of stimulation (active or sham) was performed respecting the random distribution of participants in one of the two groups studied. Randomization was carried out using numbered, opaque and sealed envelopes to ensure confidentiality. Each envelope contained a card stipulating which initial intervention the participant would be allocated to. This process was done by a team member who was not involved in the process of recruiting or developing the research. In this way, neither the participants (and their parents or responsible), nor the evaluators who applied the scale knew which group they were assigned to. In both experimental and control groups, the anode electrode was positioned over the left DLPFC and the cathode over the contralateral deltoid muscle. In the control group, the stimulator was turned on for 30 seconds, then turned off, so the participants could experience the initial sensation of the current, but not receiving the stimulation for the remaining time. After 3 months wash-out, the groups were crossed and underwent a new 10-day intervention step (active or sham). Motor outcomes were assessed by the Motor Development Scale of Francisco Rosa Neto (EDM in Portuguese: Escala de Desenvolvimento Motor) in the pre, post (10 days) and 3 months after interventions. EDM consists of test batteries that 
assess the motor development of children between six and eleven years old, and covers 6 dimensions of human motricity, as well as laterality (preference for laterality in hands, eyes and feet). Assessment tests are carried out according to the child's age group, at progressive levels of difficulty. Motor age is calculated based on the test results for each area, expressed in months. General motor age (IMG- in Portuguese: Idade Motora Geral) is calculated by adding the results of each area expressed in months, divided by 6 (number of areas evaluated, that are: fine motor skills, global motor skills, balance, body scheme, spatial organization and temporal organization and language). RESULTS: Eighteen children and adolescents completed all stages of intervention and evaluations, 14 males and 4 females, with an average age of 8.7 years (SD $=1.95$ ). The first assessment results showed that all participants had a lower IMG (motor general age) for their chronological age, showing a delay in motor development. No moderate or severe adverse effects were observed throughout the study. The Kolmogorov-Smirnov test showed normal data distribution. Thus, parametric tests were performed and the data were expressed as mean and standard deviation. The analysis of variance of repeated measures (ANOVA), with the Bonferroni post hoc test were used to determine the effect of anodic tDCS on DLPFC (active and sham) on the motor variables studied. A value of $p<0.05$ was considered indicative of statistical significance. The ANOVA of repeated measures showed a significant difference in the IMG $(F(1.9)=3.7 ; p=0.01)$. Specifically, the post hoc analysis demonstrated that compared to the intervention involving transcranial sham stimulation, the intervention with active tDCS resulted in higher averages in the follow-up assessment three months after the end of the intervention at IMG ( $p<0.05$ for all comparisons) as shown in Graph 1.

Graph 1. IMG pre-intervention, post and 3-month follow-up. * $P<0.05$

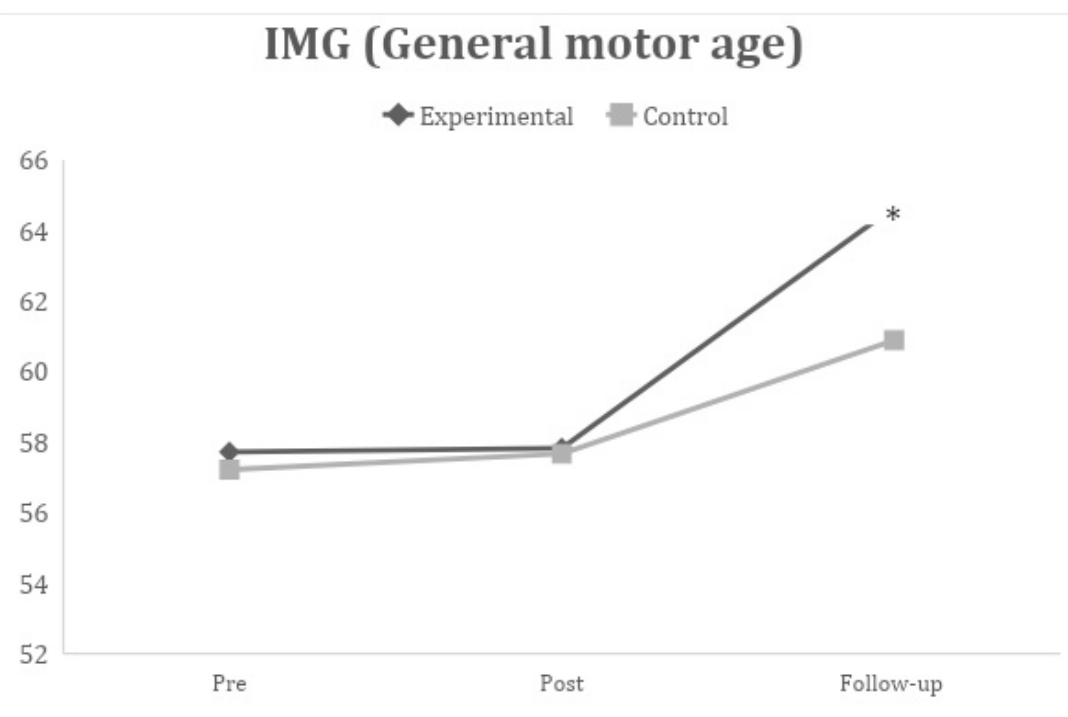

Table 1 presents the results in means and standard deviation for each intervention:

Table 1. IMG expressed in means and standard deviation; * $P<0.05$

\begin{tabular}{|cccc|ccc|}
\hline & & & \multicolumn{2}{c|}{ Control } \\
\hline & Pre & Post & Follow-up & Pre & Post \\
\hline IMG & $57,72 \pm 19,30$ & $57,83 \pm 17,32$ & $64,67 \pm 20,24^{*}$ & $57,22 \pm 18,99$ & $57,67 \pm 18,91$ & $60,89 \pm 19,34$ \\
\hline
\end{tabular}


The results of this study demonstrate that there was no statistically significant difference between active and sham interventions for tDCS in the pre and postintervention moments regarding to IMG. The highest averages were found in the parameters of general motor age (IMG) after interventions with active anodic tDCS in the 3-month follow- up assessments. The increase in IMG shows an improvement in the child's motor profile, that indicates a reduction in negative age, pointing out that the general motor performance was closer to the performance expected by his chronological age. Our findings corroborate with the studies included in the systematic review

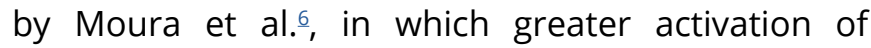
the DLPFC, promoting the reorganization of the attentional resources and the executive areas that elaborate the motor actions may have favored the motor responses, since motor tasks were oriented and demanded attention both to the commands given by the evaluator and the attention inherent in the task itself. Besides, our findings confirm the results of preliminary studies, which demonstrate that the effects of tDCS can last for three months after its application ${ }^{5,7}$. CONCLUSION: The application of anodic tDCS in the left DLPFC demonstrated positive effects on the motor responses of children and adolescents with ASD three months after its application.

KEYWORDS: Autism. Transcranial direct current stimulation. Motor Development.

\section{Contribuições dos autores}

Castro ML e Oliveira PV foram responsáveis pela execução da pesquisa e escrita do artigo. Collange LA foi responsável pela análise estatística e resultados e Muszkat M e Rizzutti S orientaram a pesquisa e fizeram a revisão do artigo.

\section{Conflitos de interesses}

Nenhum conflito financeiro, legal ou político envolvendo terceiros (governo, empresas e fundações privadas, etc.) foi declarado para nenhum aspecto do trabalho submetido (incluindo, mas não se limitando a subvenções e financiamentos, participação em conselho consultivo, desenho de estudo, preparação de manuscrito, análise estatística, etc.).

\section{Referências}

1. American Psychiatric Association. Diagnostic and Statistical Manual of Mental Disorders. 5a. ed. American Psychiatric Association; 2013

2. Baron-Cohen S, Scott FJ, Allison C, Williams J, Bolton P, Matthews FE, et al. Prevalence of autism-spectrum conditions: UK school-based population study. Br J Psychiatry. 2009;194(6):500-9. https://doi.org/10.1192/bjp.bp.108.059345

3. Warren Z, Veenstra-Vander WJ, Stone W, Bruzek JL, Nahmias AS, Foss-Feig JH, et al. Therapies for Children With Autism Spectrum Disorders. Rockville (MD): Agency for Healthcare Research and Quality (US). 2011;26. Citado em: PMID: 21834171

4. Amatachaya A, Auvichayapat N, Patjanasoontorn N, Suphakunpinyo C, Ngernyam N, Aree-Uea B, et al. Effect of Anodal Transcranial Direct Current Stimulation on Autism: A Randomized Double-Blind Crossover Trial. Behav Neurol. 2014;2014:173073. https://doi.org/10.1155/2014/173073

5. D'urso G, Bruzzese D, Ferrucci R, Priori A, Pascotto A, Galderisi $S$, et al. Transcranial direct current stimulation for hyperactivity and noncompliance in autistic disorder. World J Biol Psychiatry. 2015;16(5):361-6. https://doi.org/10.3109/15622975.2015.1014411

6. Moura MCDS, Hazime FA, Aparicio LMV, Grecco LAC, Brunoni $A R$, Hasue RH. Effects of transcranial direct current stimulation (tDCS) on balance improvement: a systematic review and metaanalysis. Somatosens Mot Res. 2019;36(2):122-35. https://doi.org/ $\underline{10.1080 / 08990220.2019 .1624517}$

7. Costanzo F, Menghini D, Casula L, Amendola A, Mazzone L, Valeri G, et al. Transcranial direct current stimulation treatment in an adolescente with autism and drug-resistant catatonia. Brain Stimul. 2015;8(6):1233-5. https://doi.org/10.1016/j.brs.2015.08.009 